\title{
Effect of starvation on RNA, DNA and protein content of laboratory-reared larvae and juveniles of Solea solea
}

\author{
Pierre Richard ${ }^{1}$, Jean-Pierre Bergeron ${ }^{2}$, Michel Boulhic $^{2}$, Robert Galois ${ }^{1}$, \\ Jeanine Person-Le Ruyet ${ }^{2}$
}

${ }^{1}$ Centre de Recherche en Ecologie marine et Aquaculture de L'Houmeau, CNRS-IFREMER, B.P. 5, F-17137 L'Houmeau, France

${ }^{2}$ Centre IFREMER de Brest, B.P. 70, F-29280 Plouzan, France

\begin{abstract}
Using analyses of individuals, dry weight, RNA, DNA and protein content were measured on the same samples to assess the nutritional status of laboratory-reared larvae and juveniles of Solea solea (L.). During the early life of $S$. solea, 2 growth periods could be distinguished by dry weight measurements and biochemical composition analysis. After metamorphosis, dry weight, RNA, DNA and protein content per individual increased more slowly than before metamorphosis. RNA, DNA and protein were strongly positively correlated to dry weight of fed larvae. Starvation led to immediate loss of weight and to decrease in RNA and protein content, while DNA amount per individual remained roughly constant. Percentage of protein relative to dry weight was always lower in starved larvae or juveniles than in fed ones. DNA and RNA percentages decreased after metamorphosis, but remained always higher in starved than in fed fish. The RNA:DNA ratio continuously decreased during starvation and could be used to discriminate starving from feeding larvae after a few days. However, the RNA:DNA ratio of fed larvae showed relatively large fluctuations during larval development, and its decrease during starvation was strongly dependent upon the ontogenetic stage. The increase of DNA relative to dry weight was also dependent upon the developmental stage of starved larvae, but was much more stable in fed larvae and juveniles. Percentage of DNA can be used to define critical levels (3\% before metamorphosis, $1.5 \%$ after it) above which larvae are undergoing starvation. The usefulness of the RNA:DNA ratio or DNA percentage as indices of nutritional condition is discussed.
\end{abstract}

\section{INTRODUCTION}

Fish recruitment variability from year to year is commonly ascribed to the success of the early life-history stages. While starvation and predation are often pointed out as the major causes of larval mortality (Shelbourne 1957, May 1974, Cushing 1975), their real and individual effects generally cannot be dissociated in the field. Starvation induces a deficient growth rate (Buckley 1982, 1984) and lengthens larval life time, thus increasing vulnerability to predation (Rice et al. 1987, Gadomsky \& Petersen 1988).

Any means to assess the nutritional condition of seacaught larvae would help in estimating larval survival and year-class fluctuations. Different methods have already been applied to that aim. Shelbourne (1957) evaluated the nutritional status of plaice larvae by arbitrarily categorizing their external appearance. Hempel \& Blaxter (1963) and Blaxter (1971) measured weight-length relationships (condition factor) in herring larvae. Morphometric measurements also can indicate starvation (Ehrlich et al. 1976, Martin \& Wright 1987) and are sometimes coupled with histological determinations (Theilacker 1978, 1986, Setzler-Hamilton et al. 1987). Chemical or biochemical methods have also been commonly applied, utilizing e.g. chemical composition of herring (Ehrlich 1974a) and plaice larvae (Ehrlich 1974b), trypsin + trypsinogen content in cod larvae (Hjelmeland et al. 1984), and nucleic acid and protein content of various fish larvae (Buckley 1980, 1981, Clemmesen 1987). All of these methods have their limits - some are too time-consuming, others require large samples or are valid only for particular larval stages.

Bulow (1970) first reported the sensitivity of the RNA:DNA ratio to changes in feeding levels. Ribonucleic acid (RNA) is involved in protein synthesis and related to growth rate (Sutcliffe 1965). Its level is 
expected to be higher in tissues or organisms showing faster growth or protein synthesis. Deoxyribonucleic acid (DNA) is associated with genetic information and is considered to be constant in the cells of somatic tissues for a given species (Regnault \& Luquet 1974). It has been proved to be very stable under changing environmental conditions or during starvation. Buckley $(1979,1980,1981)$ showed that the RNA:DNA ratio was a good indicator of growth rate, and used it as a nutritional index for diagnosis of starvation stress. However, determination of nucleic acids using the ultraviolet absorption method (Buckley 1979, Buckley \& Bulow $1987)$ required a relatively large sample size $10.8 \mathrm{mg}$ dry wt) and could not evaluate individual variability, a necessary parameter for estimating survival rate within a population. Recently, more sensitive methods have been used to study the effects of starvation on individual fish larvae (Robinson \& Ware 1988, Westerman $\&$ Holt 1988), but their results showed a much larger variability than observed on pooled samples, as well as dependence of the RNA:DNA ratio on fish age (Clemmesen 1989). Furthermore, large variation in the RNA:DNA ratio may occur in fed larvae (Clemmesen 1988, Raae et al. 1988). Therefore, use of the RNA:DNA ratio as an index of the length of starvation warrants close re-examination (Bergeron et al. in press).

The present study was undertaken to examine the relationships between changes in RNA, DNA, and protein content during the development of laboratoryreared Solea solea (L.) larvae and young juveniles. Using analysis of protein and nucleic acids on the same individual samples, the effect of starvation at different ages was investigated to determine whether measurements of these biochernical components could provide an index of nutritional condition in S. solea larvae and juveniles.

\section{MATERIALS AND METHODS}

Incubation and rearing. Eggs were obtained from the Solea solea brood stock farmed at the Centre Océanologique de Bretagne (IFREMER) and were incubated for $3.5 \mathrm{~d}$ at 10 to $11^{\circ} \mathrm{C}$, then for $2 \mathrm{~d}$ at $14{ }^{\circ} \mathrm{C}$ before hatching in a 601 open-circulation tank. Batches of ca 3000 larvae were transferred to $60 \mathrm{l}$ closedcirculation, aerated rearing tanks under a $16 \mathrm{~h}$ light: $8 \mathrm{~h}$ dark regime. The temperature was then raised up to $18-19^{\circ} \mathrm{C}$ within a few days. At that temperature, the yolk sac was completely absorbed after Day 5, and metamorphosis occurred around Days 13 to 15 . Larvae were fed young Artemia salina nauplii from the second day after hatching until starved. Dead larvae were counted and removed every day.

The effects of starvation period were measured on variously aged groups of larvae: some were fed throughout the experiment (controls), others were starved from the beginning or from 5,10 or $14 \mathrm{~d}$ after hatching.

Sampling and weight measurements. Sampling was performed on a progressive step basis, with a $1 \mathrm{~d}$ interval at the beginning of the treatment, then with 2 , 3 or 4 d intervals over the course of the experiment. For starving larvae, a sample was taken $1 \mathrm{~d}$ before the beginning of starvation. Larvae were sampled early in the morning before feeding, thus minimizing contamination by food ingested the previous day. For each sampling interval, 5 larvae were individually removed, rinsed and pipetted into $1.5 \mathrm{ml}$ Eppendorf tubes, then immediately frozen at $-30^{\circ} \mathrm{C}$ and stored at $-80^{\circ} \mathrm{C}$. They were freeze-dried and left in a vacuum desiccator at $4{ }^{\circ} \mathrm{C}$ for $24 \mathrm{~h}$ before individual dry-weight determination on a microbalance $( \pm 1 \mu \mathrm{g}$ ). To obtain a precise value of dry weight, especially for the smallest larvae, freshly activated silica gel was placed in the balance in order to control for relative hygrometry. Time from removal from the desiccator to weighing was controlled strictly.

Biochemical analyses. Each of the freeze-dried larvae was homogenized in $0.5 \mathrm{ml}$ of ice-cold phosphate buffer saline (PBS), pH 7.5 (Karsten \& Wollenberger 1972), with an all-glass hand microhomogenizer.

Protein determination: Proteins were measured as primary amines after acid hydrolysis, derivatization with o-phthaldialdehyde and fluorescence detection; $50 \mu \mathrm{l}$ of the homogenate (or Bovine Serum Albumine as a standard) were pipetted with $150 \mu \mathrm{l}$ of $8 \mathrm{M} \mathrm{HCl}$ into $8 \mathrm{ml} \mathrm{screw}$ cap tubes and hydrolysed at $105^{\circ} \mathrm{C}$ for $22 \mathrm{~h}$. Then $400 \mu$ lof $3 \mathrm{M} \mathrm{NaOH}$ and $400 \mu \mathrm{l}$ of $0.4 \mathrm{M}$ borate buffer (pH 10.4) were added.

Protein measurements were carried out on a Kontron Anacomp 220 HPLC system used as an automatic analyser; a teflon tube $(0.3 \mathrm{~mm}$ i.d:; $1.5 \mathrm{~m}$ long) was substituted for the column. The elution buffer, made daily, was a $0.4 \mathrm{M}$ borate buffer ( $\mathrm{pH} 10.4)$ containing the OPA reagent $[650 \mathrm{mg}$ o-phthaldialdehyde (Fluka) dissolved in $10 \mathrm{ml}$ ethanol and $2 \mathrm{ml}$ of mercaptoethanol (Prolabo) per litre]. Flow was adjusted to $0.8 \mathrm{ml} \mathrm{min}^{-1}$ to insure a $30 \mathrm{~s}$ minimum reaction time. Samples were injected through a valve fitted with a $100 \mu$ loop. Fluorescence detection was made by a Kontron spectrofluorometer SFM 25 (excitation at $340 \mathrm{~nm}$, emission at $450 \mathrm{~nm}$ ) and resulting peaks were quantified by area integration.

DNA and RNA determinations: Nucleoprotein dissociation was performed using heparin (Karsten \& Wollenberger 1977). Measurement of RNA and DNA together was made by the ethidium bromide (EB) procedure (Le Pecq \& Paoletti 1966, Karsten \& Wollenberger 1972,1977 ). A second fluorescence assay using 
bisbenzimidazole (Hoechst 33258), a DNA-specific fluorochrome, gave the sample DNA value (Brunk et al. 1979, Deflaun et al. 1986, Clemmesen 1988) from a DNA-H33258 calibration curve. Calculation of the RNA value was made by substracting the corresponding DNA-EB fluorescence from the total-EB fluorescence and transferring the result to an RNA-EB calibration curve. Yeast RNA (type III) and calf thymus DNA (Sigma) were used as standards.

DNA+RNA-EB fluorescence was measured using the same analytical equipment used for proteins. The elution solution was $0.1 \mathrm{M} \mathrm{NaCl}, \mathrm{pH} 7.5$, at a flow of 1.0 $\mathrm{ml} \mathrm{min}{ }^{-1}$. The spectrofluorometer was fitted with a redsensitive photomultiplier, excitation was set at $365 \mathrm{~nm}$ and emission at $590 \mathrm{~nm}$. A $100 \mu \mathrm{l}$ aliquot of the homogenate + heparin solution was mixed with $30 \mu \mathrm{l}$ of an EB solution ( $25 \mu \mathrm{g} \mathrm{ml}^{-1}$ in $0.1 \mathrm{M} \mathrm{NaCl}$ ) and injected after 1 min through a $100 \mu l$ loop.

DNA-H33258 fluorescence was determined using 0.1 $\mathrm{M} \mathrm{NaCl}, \mathrm{pH} 9.0$, as the elution solvent. The excitation light was set at $352 \mathrm{~nm}$, the emission at $448 \mathrm{~nm}$. The homogenate + heparin solution $(50 \mu \mathrm{l})$ was mixed with $250 \mu \mathrm{l}$ of PBS. Fluorescence was measured on $150 \mu \mathrm{l}$ of the resulting solution mixed with $40 \mu \mathrm{l}$ of an $\mathrm{H} 33258$ solution $\left(0.01 \mathrm{mg} \mathrm{ml}^{-1}\right.$ in water).

For the EB and H33258 assays, the background fluorescence of each sample was determined by mixing an equal volume of elution solution, instead of the fluorochrome solution, with the sample.

\section{RESULTS}

Larvae starved from hatching survived for $9 \mathrm{~d}$, and those starved from Days 5, 10 and 14 survived for 10,12 and 16 days respectively. Metamorphosis occurred around Days 13 to 15 for fed larvae. Ontogenetic changes ceased soon after food deprivation. Thus larvae which began to metamorphose, then were starved on Day 14, never completed metamorphosis. Larvae starved from Day 2, 5 or 10 never metamorphosed.

Fig. 1 shows on a semi-logarithmic scale the variations in dry weight for fed and starved larvae and juveniles. Two periods could be recognized on the curve for fed fishes: dry weight gain was slower after metamorphosis than before.

Starvation led to immediate loss of weight. This was especially evident for larvae starved from Day 2, which in fact were never fed, since mouth opening occurred on that day. These lost $60 \%$ of their initial weight before all larvae died on Day 11. The weight decrease was not so obvious in the other groups that were starved. Larvae starved from Days 5 and 10 lost up to a maximum of ca $40 \%$, and larvae starved from Day 14 ca $35 \%$.

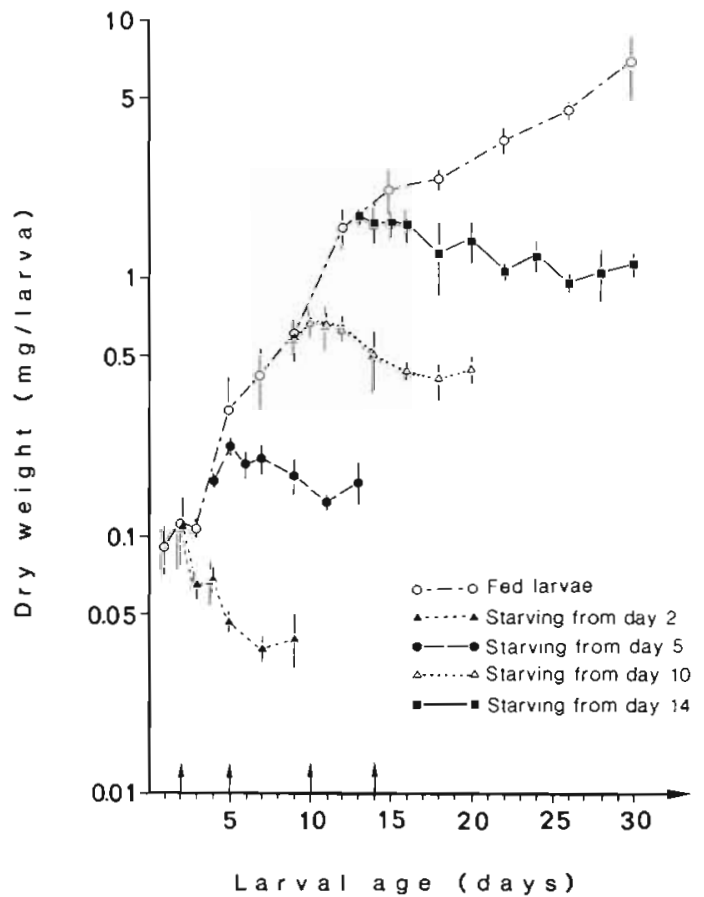

Fig. 1. Solea solea. Variations in dry weight $\left(\mathrm{mg} \mathrm{larva}^{-1}\right.$, semilogarithmic scale) of fed and starved larvae during larval development. Each point is the mean $\pm \mathrm{SD}$ of 5 measurements. Arrows indicate start of food deprivation

Amounts of protein, RNA and DNA increased with age in fish that were fed (Figs. $2,3 \& 4$ ). Protein and RNA content of starving larvae behaved in the same way as dry weight.

The decrease in RNA content began $1 \mathrm{~d}$ after the beginning of starvation, except for the larvae that were never fed. DNA content showed a quite different evolution during starvation. Some increase occurred during the first day of food deprivation, and the subsequent decrease was not significant (Fig. 4). The relationships between dry weight and protein, RNA and DNA content, linearized by logarithmic transformation, are given in Table 1

As shown in Table 2, starvation induced a decrease in the protein content as a percentage of dry weight. In fed larvae, protein content amounted to $30 \%$ during yolk sac resorption, then increased up to $65 \%$ and maintained this value after metamorphosis. Except during yolk sac resorption, protein percentages were always lower in starved larvae than in fed ones.

RNA and DNA content (percentage of dry weight) showed that metamorphosis divided the larval development of Solea solea into 2 distinct periods, as seen above on the absolute RNA-age and DNA-age curves. Before metamorphosis, RNA values of fed larvae varied between 3.4 and $4.3 \%$ dry wt. They decreased to $2.0-2.5 \%$ dry wt after Days 13 to 15 . In starved fish, percentage RNA also decreased after 


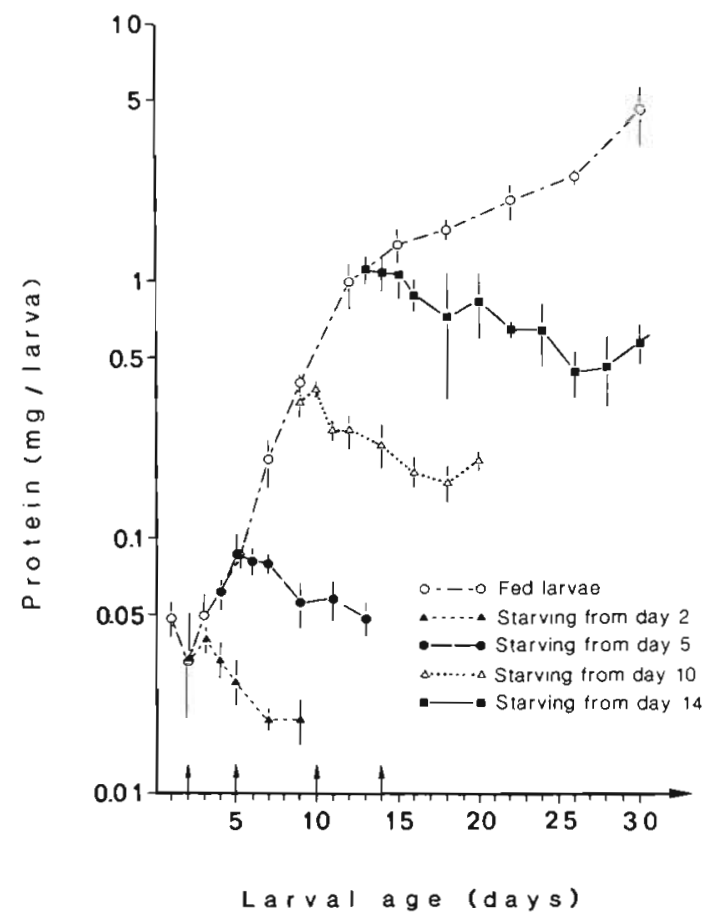

Fig. 2. Solea solea. Variations in protein content (mg larva ${ }^{-1}$, semi-logarithmic scale) of fed and starved larvae during larval development. Each point is the mean \pm SD of 3 to 5 measurements. Arrows indicate start of food deprivation

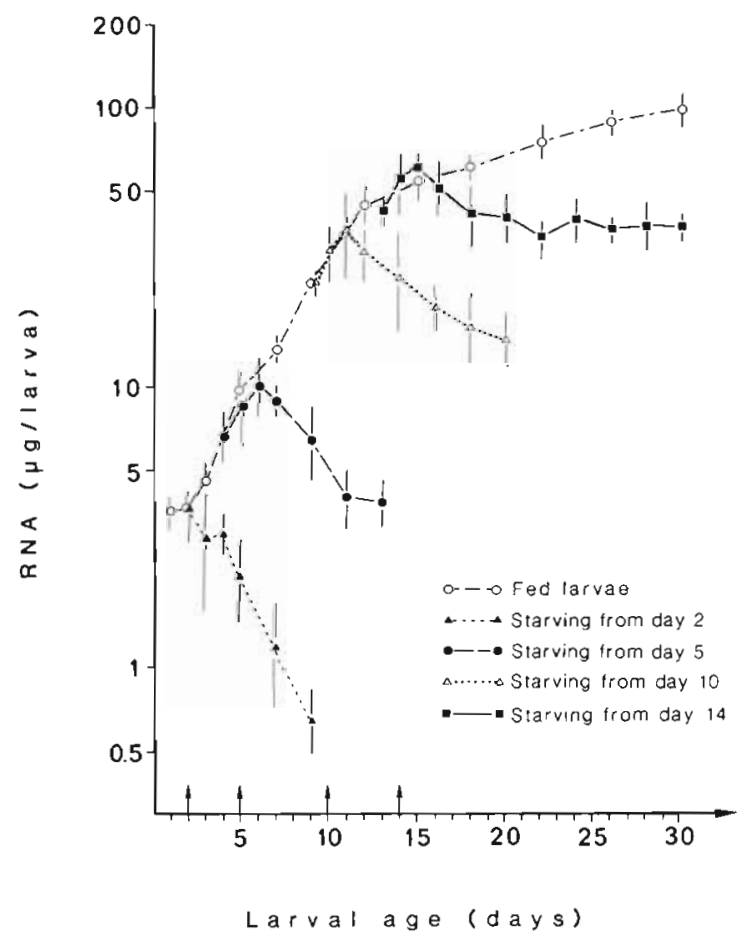

Fig. 3. Solea solea. Variations in RNA content ( $\mu$ g larva ${ }^{-1}$, semi-logarithmic scale) of fed and starved larvae during larval development. Data points and arrows as in Fig. 2

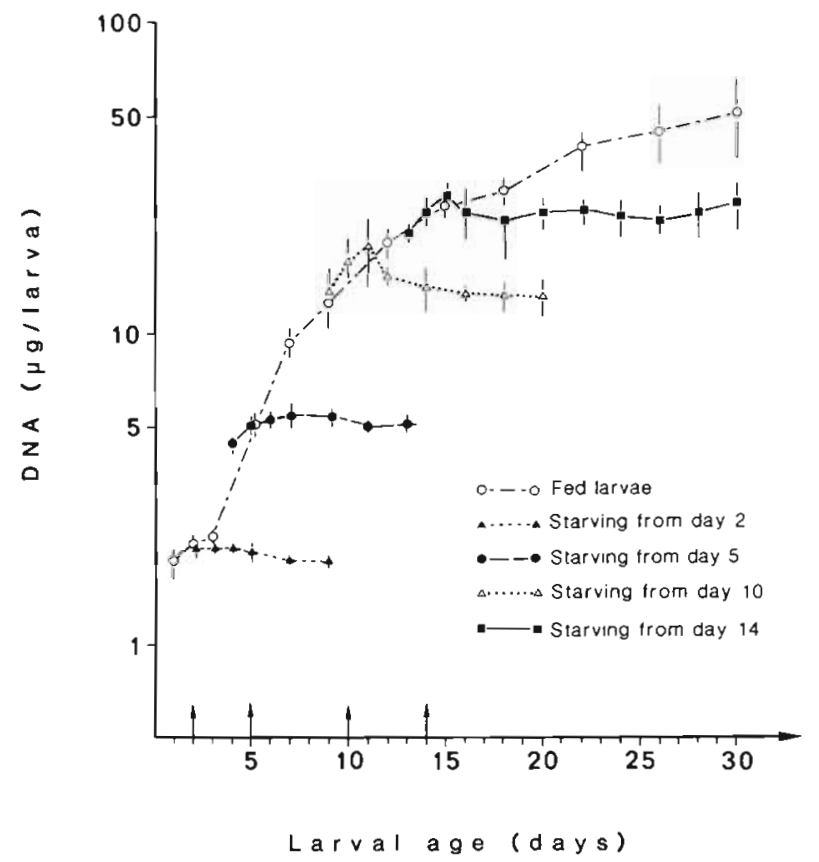

Fig. 4. Solea solea. Variations in DNA content ( $\mathrm{ug}$ larva $^{-1}$, semi-logarithmic scale) of fed and starved larvae during larval development. Data points and arrows as in Fig. 2

Table 1. Solea solea. Linearized regression equations for dry weight vs protein, dry weight vs RNA and dry weight vs DNA for fed larvae. Dry weight is the independent variable $(X)$; all variables in $\mu \mathrm{g}$ larva $^{-1}$

\begin{tabular}{|lccc|}
$\begin{array}{l}\text { Dependent } \\
\text { variable }\end{array}$ & $N$ & $\begin{array}{c}\text { Regression } \\
\text { equation }\end{array}$ & $\begin{array}{c}\text { Correlation } \\
\text { coefficient }\end{array}$ \\
\hline Protein & 51 & $\ln Y=1.135 \ln X-1.584$ & 0.987 \\
RNA & 49 & $\ln Y=0.821 \ln X-2.358$ & 0.984 \\
DNA & 49 & $\ln Y=0.789 \ln X-2.803$ & 0.985 \\
\hline
\end{tabular}

metamorphosis, but stayed always equal to or higher than that in fed larvae.

Before metamorphosis, DNA content in fed larvae amounted to ca $2.1 \%$ (Fig. 5), with rather large variability (extreme values from 1.4 to $3.2 \%$ dry wt). After metamorphosis it was very stable, around $1.2 \%$, with remarkably low variability. It was always higher in starved larvae than in fed ones, and always increased with length of starvation, except for the last samples prior to mass death of larvae.

Data obtained during these experiments were used to calculate the RNA:DNA ratios for the fed and starved batches (Fig. 6). Average RNA:DNA ratios were calculated as ratios of the average RNA and DNA values for each experimental treatment, but the confidence intervals of the means could not be computed since the number of replicates was very low (Scherrer 1984). Overall during ontogenetic development the mean 
Table 2. Solea solea. Comparison of protein and RNA contents (\% of dry weight \pm SD) between larvae of the same age, fed or starved from different times after hatching. Data are calculated using 5 individual measurements, except those marked by one asterisk (3 measurements) or two asterisks (4 measurements)

\begin{tabular}{|c|c|c|c|c|}
\hline \multirow{2}{*}{$\begin{array}{l}\text { Age } \\
\text { (d) }\end{array}$} & \multicolumn{2}{|c|}{ Protein content } & \multicolumn{2}{|c|}{ RNA content } \\
\hline & Fed & Starved & Fed & Starved \\
\hline \multicolumn{5}{|c|}{ Larvae starved from Day 2} \\
\hline 1 & $49.6 \pm 6.4^{\cdots}$ & - & $4.2 \pm 1.5^{\cdots}$ & - \\
\hline 2 & $28.9 \pm 7.2$ & $27.8 \pm 11.7$ & $3.5 \pm 1.3$ & $3.1 \pm 0.6$ \\
\hline 3 & $45.7 \pm 10.8$ & $62.2 \pm 4.0$ & $4.3 \pm 0.9 \cdots$ & $4.4 \pm 1.7$ \\
\hline 4 & - & $49.3 \pm 12.5^{\cdots}$ & - & $4.3 \pm 0.9 \cdots$ \\
\hline 5 & $32.7 \pm 16.2 \cdots$ & $59.9 \pm 6.2 \cdots$ & $3.7 \pm 1.5^{\cdots}$ & $4.4 \pm 1.3^{\cdots}$ \\
\hline 7 & $47.3 \pm 7.3$ & $53.8 \pm 8.2$ & $3.5 \pm 1.3$ & $3.3 \pm 1.3$ \\
\hline 9 & $65.4 \pm 2.0^{\circ}$ & $49.2 \pm 14.4$ & $3.9 \pm 0.5^{\circ}$ & $1.7 \pm 0.5$ \\
\hline \multicolumn{5}{|c|}{ Larvae starved from Day 5} \\
\hline 5 & $32.7 \pm 16.2 \cdots$ & $39.8 \pm 4.9$ & $3.7 \pm 1.5$ & $4.0 \pm 1.1$ \\
\hline 6 & - & $42.8 \pm 3.0^{\cdots}$ & - & $5.4 \pm 1.2$ \\
\hline 7 & $47.3 \pm 7.3$ & $40.4 \pm 5.4$ & $3.4 \pm 0.9$ & $4.6 \pm 0.7$ \\
\hline 9 & $65.4 \pm 2.0^{\circ}$ & $32.4 \pm 3.6$ & $3.9 \pm 0.5^{\circ}$ & $3.8 \pm 1.0$ \\
\hline 11 & - & $41.8 \pm 5.3$ & - & $3.0 \pm 0.6$ \\
\hline 12 & $62.1 \pm 5.2^{\cdots}$ & - & $2.8 \pm 0.2 \cdots$ & - \\
\hline 13 & - & $30.6 \pm 7.5$ & - & $2.4 \pm 0.3$ \\
\hline \multicolumn{5}{|c|}{ Larvae starved from Day 10} \\
\hline 10 & - & $56.4 \pm 6.8$ & - & $4.6 \pm 1.4$ \\
\hline 11 & - & $38.2 \pm 4.7 \cdots$ & - & $5.7 \pm 2.5$ \\
\hline 12 & $62.1 \pm 5.2 \cdots$ & $40.8 \pm 3.6$ & $2.8 \pm 0.2 \cdots$ & $4.8 \pm 1.1$ \\
\hline 14 & - & $45.4 \pm 5.6$ & - & $4.9 \pm 1.1$ \\
\hline 15 & $61.4 \pm 4.2$ & - & $2.5 \pm 0.5$ & - \\
\hline 16 & - & $41.3 \pm 7.4$ & - & $4.4 \pm 0.9$ \\
\hline 18 & $65.8 \pm 3.6$ & $40.3 \pm 3.1$ & $2.5 \pm 0.1$ & $4.0 \pm 0.6$ \\
\hline 20 & - & $45.2 \pm 8.0$ & - & $3.4 \pm 1.0$ \\
\hline \multicolumn{5}{|c|}{ Larvae starved from Day 14} \\
\hline 14 & - & $63.7 \pm 2.6^{\cdots}$ & - & $3.4 \pm 0.7$ \\
\hline 15 & $61.4 \pm 4.2$ & $64.4 \pm 7.4$ & $2.5 \pm 0.5$ & $3.7 \pm 0.5$ \\
\hline 16 & - & $55.5 \pm 12.9^{\cdots}$ & - & $3.2 \pm 0.8$ \\
\hline 18 & $65.8 \pm 3.6$ & $56.0 \pm 12.1 \cdots$ & $2.5 \pm 0.1$ & $3.4 \pm 0.4$ \\
\hline 20 & - & $58.8 \pm 11.1$ & - & $3.0 \pm 0.4$ \\
\hline 22 & $59.8 \pm 10.9^{\circ}$ & $60.5 \pm 1.9$ & $2.3 \pm 0.1^{\circ}$ & $3.3 \pm 0.6$ \\
\hline 24 & - & $51.3 \pm 14.4$ & - & $3.3 \pm 0.6$ \\
\hline 26 & $57.1 \pm 0.2$ & $45.4 \pm 10.3$ & $2.0 \pm 0.3^{\circ}$ & $3.9 \pm 0.3$ \\
\hline 28 & - & $44.4 \pm 3.4 \cdots$ & - & $3.6 \pm 0.2$ \\
\hline 30 & $64.6 \pm 5.9^{\circ}$ & $51.3 \pm 8.8$ & $1.6 \pm 0.3^{\circ}$ & $3.6 \pm 0.5^{\cdots}$ \\
\hline
\end{tabular}

RNA:DNA ratio was around 2 in fed larvae, with successive decreases and increases and very high individual variability. For each batch of starved larvae, the RNA:DNA ratio was lower than in fed ones and always decreased with length of food deprivation. As with percentage DNA, the slopes were steeper for young larvae than for older fish. However, a clear distinction can never be made during the first days of starvation. Larvae starved from the beginning showed a sharp decrease in the RNA:DNA ratio, and could be distinguished from fed larvae after 2 or $3 \mathrm{~d}$ of starvation (Fig. 6). But for larvae starved after Days 5 and 10 , the food deprivation interval must be longer to show a clear effect, and in juveniles starved after Day 14 (after metamorphosis), the RNA:DNA ratio was not significantly different from that for fed juveniles throughout the experiment.

\section{DISCUSSION}

\section{Ontogenetic changes in fed larvae}

We observed a net change in the growth pattern of fed larvae after metamorphosis. Whether that decrease is normal during the ontogeny of Solea solea, or due to inadequate nutritional value of the food supply during rearing, remains in question. However, it has been noted elsewhere that biochemical composition of fish depends on developmental stage (Love 1970, Ehrlich $1974 \mathrm{a}$, b). Metamorphosis in flatfish larvae does not lead to such drastic changes as observed in leptocephalous larvae of the bonefish, which lose half of their dry weight (Pfeiler \& Luna 1984). Nevertheless, tissue reorganization does occur, which can produce 


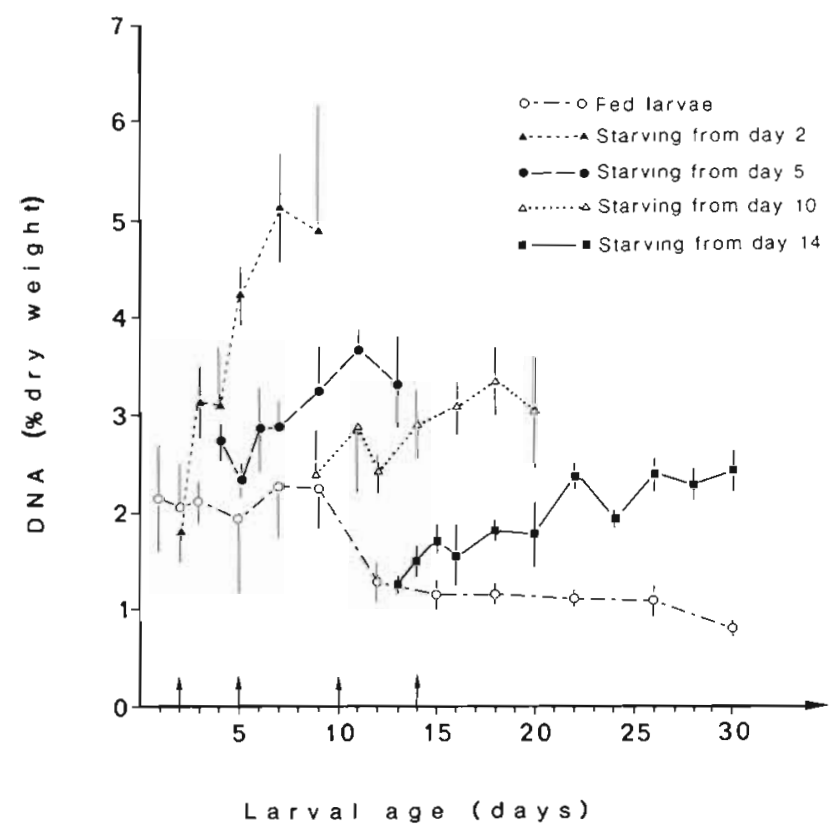

Fig. 5. Solea solea. Variations in DNA content relative to dry weight of fed and starved larvae during larval development. Data points and arrows as in Fig. 2

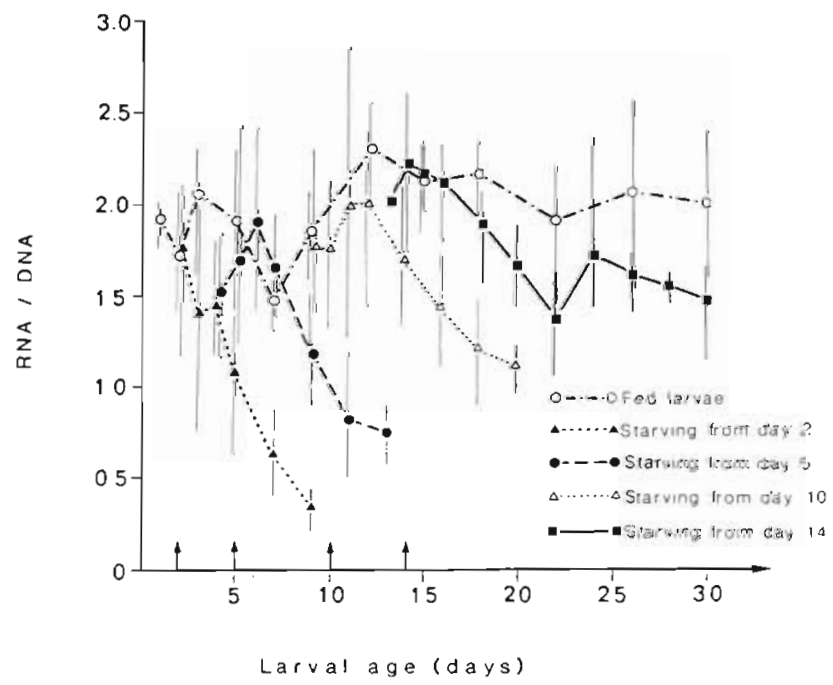

Fig. 6. Solea solea. Variations in the RNA:DNA ratio of fed and starved larvae during larval development. Each point is the ratio of the means (see 'Results'); vertical bars indicate range

differences in biochemical composition, but above all, behavioural changes coupled with morphological changes lead to variation in the general metabolism (Bergeron 1982) and energy expenditure during later development. After metamorphosis, flatfish larvae are less active (Blaxter \& Staines 1971) and have been shown to be more resistant to starvation (Clemmesen 1987, Yin \& Blaxter 1987).

Protein, RNA and DNA were closely related to dry weight in fed Solea solea larvae. Chemical changes generally are more closely linked to larval size than to age (Ehrlich 1974a, Buckley 1981). Our values for protein content (\% dry weight) are much higher than those of Clemmesen (1987) for herring and turbot larvae. This may be due to the different analytical methods used. However, as for these larvae, protein content of $S$. solea larvae increases during ontogenetic development.

Large variations and high individual variability in the RNA:DNA ratio were found in fed Solea solea larvae. Such large variations during ontogenetic development were also shown by Clemmesen (1987) in herring and turbot larvae and by Raae et al. (1988) in cod larvae.

The overall mean of the RNA:DNA ratio determined here for fed Solea solea larvae was around 2. That value is slightly lower than for reared Clupea harengus and Scophthalmus maximus larvae $(2.4$; Clemmesen 1987 ), but in many other studies the ratio was between 3 and 4 (Buckley 1980, 1982, 1984, Buckley et al. 1984, Wright \& Martin 1985). RNA:DNA ratio in reared larvae is generally much lower than in sea-caught larvae, where values of 6 to 8 are common (Buckley 1984, Robinson \& Ware 1988, Clemmesen 1989). Raae et al. (1988) found mean RNA:DNA ratios of ca 4.5 in Gadus morhua larvae fed on Brachionus sp. in tanks, and from 6 to 13 in larvae feeding on natural plankton in ponds. Prey offered to reared larvae may be of lower nutritional quality than wild plankton, and data from wild and reared larvae must be compared cautiously.

\section{Effects of starvation}

Four to five days after yolk depletion, all Solea solea larvae that were not fed were dead in our experiments Resistance to food deprivation is known to be clearly correlated with the amount of yolk available. McGurk (1984) showed from data for 25 species of marine fishes, including $S$. solea, that the time from fertilization to the age of irreversible starvation was positively correlated with the time needed to complete yolk resorption and negatively correlated with temperature. $S$ solea exhibits intermediate resistance to food deprivation compared to species with small eggs and yolk-sac larvae such as Engraulis mordax (Lasker et al. 1970), Paralichtys californicus or Hypsopsetta guttulata (Gadomski \& Petersen 1988), and to species carrying larger yolk reserves, such as Clupea harengus (Blaxter \& Hempel 1963) or Ammodytes americanus (Buckley et al. 1984).

Data presented here about the effect of starvation on biochemical composition of Solea solea larvae are in good agreement with those in the literature for other species (Buckley 1980, 1981, Raae et al. 1988). The decrease in dry weight and protein content of starved 
larvae between mouth opening and complete yolk sac resorption shows that the yolk reserve is not sufficient to ensure sustained growth, and confirms the critical importance of food availability in initiation of feeding (Buckley 1980).

Even fed larvae showed a slight decrease in dry weight on Day 3, which could have been due to their learning how to capture prey. During the learning period, larvae waste a lot of energy in searching for food (Blaxter \& Staines 1971) and cannot lay down new reserves. If food is not available at that time, yolk energy supply is quickly exhausted and feeding ability decreases even more rapidly. Therefore, such larvae could really experience complete starvation in the sea. The situation may be different for older larvae, which have more reserve substances, do not need a learning period to capture prey, and are able to eat a wider range of prey. Studies of starvation on older larvae have shown a high interspecific variability in resistance to food deprivation (Gadomski \& Petersen 1988), but flatfish larvae are generally much more resistant than pelagic larvae, particularly after metamorphosis (Blaxter \& Ehrlich 1974).

Variations in RNA per larva (Fig. 3) clearly point out the effect of starvation and the influence of developmental stage on protein synthesis potential. RNA content decreased much more quickly for larvae that were never fed. Buckley (1981) made similar observations for cod larvae. Protein content per larva, as for RNA, decreased during starvation, while DNA remained at the same level. Relative to dry weight, protein content was lower in starved larvae while, contrary to the results of Clemmesen (1987), RNA content was higher than in fed fish, except in the youngest larvae, but decreased during starvation. As shown in other studies on different species (Bulow 1970, Buckley 1979, Clemmesen 1987), percentage DNA increased with length of starvation interval regardless of the age of starved larvae, particularly in larvae that were never fed, as a result of the fast weight decrease occurring in these larvae.

\section{Nucleic acids as indices of starvation}

Since during starvation RNA content per individual decreases while DNA content is roughly constant, the RNA:DNA ratio has been extensively used as a nutritional index (Buckley et al. 1984, Buckley \& Lough 1987).

The RNA:DNA ratios calculated from our results decreased soon after the start of food deprivation; consequently, the RNA:DNA ratio could be used to determine whether a larva were suffering starvation. However, as in turbot larvae (Clemmesen 1987), RNA:DNA ratio appeared in our experiments to be dependent on developmental stage. Its rapid decrease in young larvae allowed a clear distinction between starving and fed larvae after a few days, while after metamorphosis the differences between the 2 groups were far less evident. Therefore, from our results, RNA:DNA ratio could be used only for comparison between larvae of the same stage. The same conclusion was reached by Westerman \& Holt (1988), who found large variations in the RNA:DNA ratio due to differences in the rate of increase of RNA and DNA during the early larval stages of red drum.

From data obtained on pooled samples of herring and turbot larvae, Clemmesen (1987) presented a general model of the relationship between the length of the starvation interval, the logarithm of dry weight per larva and the RNA:DNA ratio, the main part of the overall variability being explained by the latter 2 parameters. Similar use of our whole data set did not yield a satisfactory model, as it explained only $28 \%$ of the variability. This may be due to differences in the analytical methodologies. In our experiments, which analyzed biochemical components of individual fish, the RNA data were highly variable for pre-metamorphosed larvae, leading to fluctuating RNA:DNA ratios. Moreover, the larvae had high background values for RNA + DNA analysis. We cannot exclude the possible presence of stage-dependent interfering substances. To avoid such problems, it would be better to purify the nucleic acid samples before analysis, as suggested by Clemmesen (1988). However, results of the few studies based on individual measurement of nucleic acids show a higher variability in the resulting RNA:DNA ratio (Robinson \& Ware 1988), even after purification of the samples (Clemmesen 1989). The variability in the RNA:DNA ratio seems therefore to be real but is lower when pooled samples are analysed.

The percentage of DNA relative to dry weight was much more stable in fed larvae than was the RNA:DNA ratio. We cannot compare our results with those of other studies using individual measurements since they do not give data on this parameter (Robinson \& Ware 1988 , Clemmesen 1989). In our study, variation in percentage DNA relative to dry weight during larval development showed clearly the distinction between starving and feeding larvae and revealed 2 critical levels depending on larval stage. Before metamorphosis, one could consider that larvae were undergoing starvation when DNA content ( $\%$ dry wt) rose above 3 , and above 1.5 for juveniles. These results confirm the conclusions of Bergeron et al. (in press): percentage DNA relative to dry weight may be a better and simpler index of larval nutritional status than the RNA:DNA ratio, since it is more stable in fed larvae and since measurement of DNA alone is easier and more sensitive. 
In Solea solea larvae, all the indices of nutritional status, based on dry weight, protein or nucleic acid composition, were dependent on developmental stage. Nevertheless, subdivision of the larval period into a few stages might be sufficient for interpretation of such biochemical indices. In particular, the percentage DNA relative to dry weight needs only 2 subdivisions, easily distinguished by metamorphosis.

The first days after initiation of feeding seem to be of critical importance (Buckley 1980). Fortunately, indices based on nucteic acids are more sensitive in young larvae, and thus they can be very useful to assess larval nutritional condition. Due to the sensitivity of fluorometric measurements, individual analyses can be performed (Robinson \& Ware 1988, Clemmesen 1989, present study) and can give an estimate of the variability in nutritional status within a population.

Acknowledgements. This work was supported by the C.N.R.S and IFREMER through the Programme National sur le Déterminisme du Recrutement (contract no. 87-5-51-1010). We gratefully thank J. C. Alexandre for his kind assistance in rearing larvae. Three anonymous reviewers provided helpful comments in an earlier version of this manuscript.

\section{LITERATURE CITED}

Bergeron, J.-P. (1982). L'aspartate transcarbamylase, indice de croissance des organismes marins: perspectives et limites. Publs Cent. natn. Exploit. Océans (CNEXO) (Sér Act. Colloques) $14 \cdot 177-192$

Bergeron, J.-P., Boulhic, M., Galois, R. (in press). Effet de la privation de nourriture sur la teneur en ADN de la larve de sole (Solea solea L.). J. Cons. int. Explor. Mer

Blaxter, J. H. S. (1971). Feeding and condition of Clyde herring larvae. Rapp. P.-v. Réun. Cons perm. int. Explor Mer 160: $125-136$

Blaxter, J. H. S., Ehrlich, K. F. (1974). Changes in behavior during starvation of herring and plaice larvae. In: Blaxter, J.H.S. (ed.) The early life history of fish. Springer-Verlag, Berlin, p. 575-588

Blaxter, J. H. S., Hempel, G. (1963). The influence of egg size on herring larvae (Clupea harengus L.). J. Cons. int. Explor Mer 28: 211-240

Blaxter, J. H. S., Staines, M. E. (1971). Food searching potential in marine fish larvae. In: Crisp, D.J. (ed.) Proceedings 4th European Marine Biology Symposium. Cambridge University Press, Cambridge, p. 467-481

Brunk, C. F, Jones, K. C., James, T. W. (1979). Assay for nanogram quantities of DNA in cellular homogenates. Analyt. Biochem. 92: 497-500

Buckley, L. J. (1979). Relationship between RNA/DNA ratio, prey density and growth rate in Atlantic cod (Gadus morhual larvae. J. Fish. Res. Bd Can. 36: 1497-1502

Buckley, L. J. (1980). Changes in ribonucleic acid, deoxyribonucleic acid, and protein content during ontogenesis in winter flounder, Pseudopleuronectes americanus, and effect of starvation. Fish. Bull. U.S. 77. 703-708

Buckley, L. J. (1981). Biochemical changes during ontogenesis of cod (Gadus morhua L.) and winter flounder (Pseudopleuronectes americanus) larvae. Rapp. P.-v. Réun. Cons. int. Explor. Mer 178: 547-552
Buckley, L. J. (1982). Effects of temperature on growth and biochemical composition of larval winter flounder Pseudopleuronectes americanus. Mar Ecol. Prog. Ser. 8: 181-186

Buckley, L. J. (1984). RNA-DNA ratio: an index of larval fish growth in the sea. Mar. Biol. 80: 291-298

Buckley, L. J., Bulow, F. J. (1987). Techniques for the estimation of RNA, DNA, and protein in fish. In: Summerfelt, R. C., Hall, G. E. (eds.) The age and growth of fish. The Iowa State University Press, Ames, p. 345-354

Buckley, L. J., Lough, R. G. (1987). Recent growth, biochemical composition, and prey field of larval haddock (Melanogrammus aeglefinus) and atlantic cod (Gadus morhua) on Georges Bank. Can. J. Fish. Aquat. Sci. 44: $14-25$

Buckley, L. J., Turner, S. I., Halavik, T A., Smigielski, A. S. Drew, S. M., Laurence, G. C. (1984). Effects of temperature and food availability on growth, survival, and RNA-DNA ratio of larval sand lance (Ammodytes americanus). Mar Ecol. Prog. Ser. 15: $91-97$

Bulow, F. J. (1970). RNA-DNA ratios as indicators of recent growth rates of a fish. J. Fish. Res. Bd Can. 27: 2343-2349

Clemmesen, C. M. (1987). Laboratory studies on RNA/DNA ratios of starved and fed herring (Clupea harengus) and turbot (Scophthalmus maximus) larvae. J. Cons. int. Explor. Mer 43: 122-128

Clemmesen, C. (1988). A RNA and DNA fluorescence technique to evaluate the nutritional condition of individual marine fish larvae. Meeresforsch. 32: 134-143

Clemmesen, C. (1989). RNA/DNA ratios of laboratory-reared and wild herring larvae determined with a highly sensitive fluorescence method. J. Fish Biol. 35 (Suppl. A): 331-333

Cushing, D. H. (1975). Marine ecology and fisheries. Cambridge University Press, Cambridge

Deflaun, M. F., Paul, J. H., Davis, D. (1986). Simplified method for dissolved DNA determination in aquatic environments. Appl. environ. Microbiol. 52: 654-659

Ehrlich, K. F. (1974 a). Chemical changes during growth and starvation of herring larvae. In: Blaxter, J. H. S. (ed.) The early life history of fish. Springer-Verlag, Berlin, p. $301-323$

Ehrlich, K. F. (1974 b). Chemical changes during growth and starvation of larval Pleuronectes platessa. Mar Biol. 24: $39-48$

Ehrlich, K. F., Blaxter, J. H. S., Pemberton, R. (1976). Morphological and histological changes during the growth and starvation of herring and plaice larvae. Mar. Biol. 35: $105-118$

Gadomski, D. M., Petersen, J. H. (1988). Effects of food deprivation on the larvae of two flatfishes. Mar. Ecol. Prog. Ser 44: 103-111

Hempel, G., Blaxter, J. H. S. (1963). On the condition of herring larvae. Rapp. P.-v. Réun. Cons. perm. int. Explor Mer 154: 35-40

Hjelmeland, K., Huse, I., Jorgensen, T., Molvik, G., Raa, J. (1984). Trypsin and trypsinogen as indices of growth and survival potential of cod (Gadus morhua L.) larvae. In: Dahl, E., Danielssen D.S., Moksness E., Solemdal, P. (eds.) The propagation of cod Gadus morhua L., Part 1. Flodevigen rapportser 1. 189-202

Karsten, U., Wollenberger, A. (1972). Determination of DNA and RNA in homogenized cells and tissues by surface fluorometry. Analyt. Biochem. 46: 135-148

Karsten, U., Wollenberger, A. (1977). Improvements in the ethidium bromide method for direct fluorometric estimation of DNA and RNA in cell and tissue homogenates. Analyt. Biochem. 77: 464-470

Lasker, R., Feder, H. M., Theilacker, G. H., May, R. C. (1970). 
Feeding, growth, and survival of Engraulis mordax larvae reared in the laboratory. Mar. Biol. 5: 345-353

Le Pecq, J.-B., Paoletti, C. (1966). A new fluorometric method for RNA and DNA determination. Analyt. Biochem. 17: $100-107$

Love, R. M. (1970). The chemical biology of fishes. Academic Press, New York

Martin, F. D., Wright, D. A. (1987). Nutritional state analysis and its use in predicting striped bass recruitment: laboratory calibration. In: Hoyt, R.D. (ed.) 10th Annual Larval Fish Conference. AFS Symposium No 2. American Fisheries Society, Bethesda, Maryland, p. 109-114

May, R. C. (1974). Larval mortality in marine fishes and the critical period concept. In: Blaxter, J. H. S. (ed.) The early life history of fish. Springer-Verlag, Berlin, p. 3-19

McGurk, M. D. (1984). Effects of delayed feeding and temperature on the age of irreversible starvation and on the rates of growth and mortality of Pacific herring larvae. Mar. Biol. $84: 13-26$

Pfeiler, E., Luna, A. (1984). Changes in biochemical composition and energy utilization during metamorphosis of leptocephalous larvae of the bonfish (Albula). Environ. Biol. Fish. 10: 243-251

Raae, A. J., Opstad, I., Kvenseth, P., Walther, B. T (1988). RNA, DNA and protein during early development in feeding and starved cod (Gadus morhua L.) larvae. Aquaculture 73: 247-259

Regnault, M., Luquet, P. (1974). Study by evolution of nucleic acid content of prepuberal growth in the shrimp, Crangon vulgaris. Mar. Biol. 25: 291-298

Rice, J. A., Crowder, L. B., Binkowski, F. P. (1987). Evaluating potential sources of mortality for larval bloater (Coregonus hoyi): starvation and vulnerability to predation. Can. J. Fish. Aquat. Sci. 44: 467-472

Robinson, S. M. C., Ware, D. M. (1988). Ontogenic develop-

This article was submitted to the editor ment of growth rates in larval pacific herring, Clupea harengus pallasi, measured with RNA-DNA ratios in the strait of Georgia, British Columbia. Can. J. Fish. Aquat. Sci. 45: 1422-1429

Scherrer, B. (1984). Biostatistique. Gaëtan Morin, Chicoutimi, Canada

Setzler-Hamilton, E. M., Wright, D. A., Martin, F. D., Millsaps, C. V., Whitlow, S. I. (1987). Analysis of nutritional condition and its use in predicting striped bass recruitment: field studies. In: Hoyt, R. D. (ed.) 10th Annual Larval Fish Conference. AFS Symposium No 2. American Fisheries Society, Bethesda, Maryland, p. 115-128

Shelbourne, J. E. (1957). The feeding and condition of plaice larvae in good and bad plankton patches. J. mar. biol. Ass. U.K. 36: 539-552

Sutcliffe, W. H., Jr. (1965). Growth estimates from ribonucleic acid content in some small organisms. Limnol. Oceanogr. 10: R253-R258

Theilacker, G. H. (1978). Effect of starvation on the histological and morphological characteristics of jack mackerel, Trachurus symmetricus, larvae. Fish. Bull. U.S. 76: 403-414

Theilacker, G. H. (1986). Starvation-induced mortality of young sea-caught jack mackerel, Trachurus symmetricus, determined with histological and morphological methods. Fish. Bull. U.S. 84: 1-17

Westerman, M. E., Holt, G. J. (1988). The RNA-DNA ratio measurement of nucleic acids in larval Sciaenops ocellatus. Contrib. mar. Sci. 30: 117-124

Wright, D. A., Martin, F. D. (1985). The effect of starvation on RNA:DNA ratios and growth of larval striped bass, Morone saxatalis. J. Fish Biol. 27: 479-485

Yin, M. C., Blaxter, J. H. S. (1987). Feeding ability and survival during starvation of marine fish larvae reared in the laboratory. J. exp. mar. Biol. Ecol. 105: 73-83

Manuscript first received: June 26, 1990

Revised version accepted: March 5, 1991 